EXTENDED REPORT

\title{
Distinct tumour necrosis factor $\alpha$, interferon $\gamma$, interleukin 10 , and cytotoxic T cell antigen 4 gene polymorphisms in disease occurrence and end stage renal disease in Wegener's granulomatosis
}

\author{
B M Spriewald, O Witzke, R Wassmuth, R R Wenzel, M-L Arnold, T Philipp, J R Kalden
}

Ann Rheum Dis 2005;64:457-461. doi: 10.1136/ard.2004.025809

See end of article for authors' affiliations

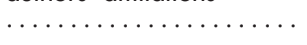

Correspondence to: Dr Bernd M Spriewald, Institute for Clinical Immunology, Department of Medicine III,

Glückstrasse 4a, 91054

Erlangen, Germany; bernd.spriewald@med3. imed.uni-erlangen.de

Accepted 22 August 2004

\begin{abstract}
Background: Cytokines and T cell regulatory proteins play an important role in the pathogenesis of Wegener's granulomatosis (WG).

Objective: To investigate cytokine and cytotoxic T cell antigen-4 (CTLA4) gene polymorphisms and HLA class II alleles in generalised WG.

Methods: The distribution of cytokine and cytotoxic T cell antigen 4 (CTLA4) gene polymorphisms and HLA class II alleles was analysed in 32 patients with generalised WG and 91 healthy controls. Genotyping was carried out for HLA-DRB 1 and HLA-DQB 1 and for polymorphism of the genes encoding TNF $\alpha(-238$, $-308,-376)$, TGF $\beta$ (codon 10 and 25), IFN $\gamma(+874)$, IL6 (-174), ILIO (-592, -819, - 1082), CTLA4 $(-318,+49)$, and the $(\text { AT })_{n}$ repeats of the CTLA4 gene. In addition, stratification analysis was carried out according to the presence $(n=15)$ or absence $(n=17)$ of end stage renal disease.

Results: An increase in the IFN $\gamma+874 \mathrm{~T} / \mathrm{T}$ (odds ratio $(O R)=3.14)$ and TNF $\alpha-238 \mathrm{G} / \mathrm{A}(\mathrm{OR}=5.01)$ genotypes was found in WG patients. When ESRD positive and negative patients were compared, the IFN $\gamma+874 \mathrm{~A} / \mathrm{A}$ and the CTLA4 $-318 \mathrm{C} / \mathrm{C}$ genotypes were found more often in the ESRD subgroup $(O R=10.6$ and $O R=2.25)$. WG patients without ESRD had a higher frequency of the IL10 GCC/ACC promotor genotype $(O R=0.13)$ and long CTLA4 $(A T)_{n}$ repeats $(O R=0.4)$. No effect was seen for HLA-DR and $-D Q$ markers.
\end{abstract}

Conclusions: Disease susceptibility and clinical course in WG may be associated with distinct polymorphisms of cytokine and CTLA4 genes.
W egener's granulomatosis (WG) is a rare disease characterised by necrotising granulomatous lesions and small vessel vasculitis. ${ }^{1}$ In its generalised form the disease mainly affects the respiratory tract and the kidneys. A characteristic feature of WG is the presence of antineutrophil cytoplasmic autoantibodies (ANCA) directed against proteinase 3 (PR3), showing a cytoplasmic staining pattern on immunofluorescence assay. Previous immunogenetic studies have suggested several associations of HLA genes with WG. ${ }^{2}$ However, despite the important role that $\mathrm{T}$ cells play in WG, no obvious and consistent HLA association was identified. ${ }^{2}{ }^{3}$ As disease heterogeneity may hamper the identification of immunogenetic factors in ANCA associated vasculitis, ${ }^{3}$ we focused our study on PR3-ANCA positive WG patients with generalised disease involving the kidneys.

Activated $\mathrm{T}$ cells can be found in granulomatous lesions and in peripheral blood from patients with generalised WG. ${ }^{4-7}$ Furthermore, the immune response in WG seems to be skewed towards a $\mathrm{T}$ helper (Th)l-like cytokine secretion pattern in granuloma derived $\mathrm{T}$ cells and in peripheral $\mathrm{T}$ cells. ${ }^{7-9}$ Proinflammatory cytokines as well as transforming growth factor $\beta$ (TGF $\beta$ ) have been shown to enhance translocation of PR3, the main target of ANCA autoantibodies in WG, to the cell surface of neutrophil leucocytes and presumably endothelial cells. ${ }^{10-12}$ Binding of ANCA to cell surface PR3 enables activation of neutrophils, which can adhere to endothelial cells following cytokine mediated upregulation of adhesion molecules, promoting vascular and tissue damage (reviewed by Reumaux et $a l^{13}$ and Harper et $\left.a l^{14}\right)$. Owing to their important role in the pathogenesis of WG, polymorphisms in cytokine and $\mathrm{T}$ cell regulatory genes have become a focus of interest for immunogenetic analyses. Recent studies suggested that both interleukin 10 (IL10) $^{15}{ }^{16}$ and cytotoxic $\mathrm{T}$ cell antigen 4 (CTLA4) polymorphisms are associated with WG. ${ }^{17}$ No association was found, however, for the -308 tumour necrosis factor $\alpha(\mathrm{TNF} \alpha)^{1718}$ and TGF $\beta$ codon 25 polymorphism. ${ }^{16}$

In the present exploratory study we analysed HLA-DRBI and HLA-DQBI alleles and polymorphisms in the interferon $\gamma$ $($ IFN $\gamma$ ) (intronl+874), TNF $\alpha$ (promotor $-238,-308,-376$ ), TGF $\beta$ (codon 10 and 25), IL6 (promotor -174), IL10 (promotor -592, $-819,-1082$ ), and CTLA4 (promotor -318 , intronl +49 , AT repeats) genes in a well defined cohort of PR3-ANCA positive patients with generalised WG and renal involvement.

\section{METHODS}

\section{Patients and controls}

Thirty two unrelated white patients with PR3-ANCA positive generalised WG were investigated after giving their informed consent. All patients fulfilled the diagnostic criteria of the American College of Rheumatology ${ }^{19}$ and the definitions of the Chapel Hill consensus conference. ${ }^{20}$ They all had generalised disease with WG related renal involvement, as indicated by raised serum creatinine or biopsy proven morphological changes.

Abbreviations: ANCA, antineutrophil cytoplasmic autoantibodies; ESRD, end stage renal disease; IFN $\gamma$, interferon $\gamma ;$ IL, interleukin; TGF $\beta$, transforming growth factor $\beta$; TNF $\alpha$, tumour necrosis factor $\alpha$; WG, Wegener's granulomatosis 
The patients were seen and treated at the department of nephrology, University Hospital Essen, Germany, and had received standard immunosuppressive therapy, based on cyclophosphamide and corticosteroids. The genotyping results of the patient cohort were compared with those of 91 healthy white controls. Subsequently, WG patients were stratified on the basis of the presence or absence of end stage renal disease (ESRD) requiring haemodialysis or kidney transplantation. The resulting subgroups were similar with regard to age at diagnosis and disease duration (table 1).

\section{DNA extraction}

DNA was extracted from peripheral blood samples using the QIAamp DNA blood kit (Qiagen, Kiel, Germany).

\section{HLA-DRB 1 and HLA-DQB 1 genotyping}

HLA-DRBI and HLA-DQBl genotyping was carried out using the ELPHA ${ }^{\circledR}$ low resolution polymerase chain reaction (PCR) single strand oligonucleotide (PCR-SSO) typing kit, according to the manufacturer's instructions (Biotest AG, Dreieich, Germany). This typing scheme allowed the resolution of HLA-DRB ${ }^{*} 01$ to ${ }^{*} 10$ including the splits of DRB1*02, ${ }^{*} 05$, and ${ }^{*} 06$, as given in table 2. For HLA-DQB1, the most common alleles were detected (table 2). No further differentiation of $\mathrm{DQBI}{ }^{*} 02$ and ${ }^{*} 04$ was undertaken.

\section{Cytokine genotyping}

The dimorphisms of the cytokine genes encoding TGF $\beta$ (codon $10 \mathrm{~T} / \mathrm{C}$ and $25 \mathrm{C} / \mathrm{G}$ ), IFN $\gamma$ (intronl $+874 \mathrm{~A} / \mathrm{T}$ ), IL6 (promoter $-174 \mathrm{C} / \mathrm{G}$ ), and IL10 (promoter $-592 \mathrm{C} / \mathrm{A},-819$ $\mathrm{C} / \mathrm{T},-1082 \mathrm{G} / \mathrm{A}$ ) were analysed using a commercial sequence specific primer amplification (PCR-SSP) assay (Cytokine Genotyping Tray, One Lambda, Canoga Park, California, USA). The cytokine phenotype with regard to high, intermediate, or low cytokine expression levels associated with the respective genotype or haplotype was named using published conventions.

\section{TNF $\alpha$ and CTLA4 sequence based typing}

The polymorphisms in the promotor region of the TNF $\alpha$ gene $(-376 \mathrm{G} / \mathrm{A},-308 \mathrm{G} / \mathrm{A},-238 \mathrm{G} / \mathrm{A})$ were analysed by direct sequence based typing (PCR-SBT) following amplification with the 5'-CAAACACAGGCCTCAGGACTC-3' forward and 5'-AGGGAGCGTCTGCTGGCTG-3' reverse primer, after 30

Table 1 Stratification of patients with Wegener's granulomatosis defined by end stage renal disease

\begin{tabular}{|c|c|c|}
\hline \multirow[b]{2}{*}{ Variable } & \multicolumn{2}{|c|}{ End stage renal disease } \\
\hline & No $(n=17)$ & Yes $(n=15)$ \\
\hline $\begin{array}{l}\text { Age at diagnosis (years) (median } \\
\text { (range)) }\end{array}$ & 54 (19 to 70$)$ & $55(25$ to 62$)$ \\
\hline $\begin{array}{l}\text { Disease duration (years) (median } \\
\text { (range)) }\end{array}$ & $5(1$ to 10$)$ & $6(1$ to 20$)$ \\
\hline IFN $\gamma+874 \mathrm{~T} / \mathrm{T}$ (high) & $7(41 \%)$ & $4(27 \%)$ \\
\hline IFN $\gamma+874 \mathrm{~A} / \mathrm{A}$ (low) & $1(6 \%)$ & $6(40 \%)^{*}$ \\
\hline TNF $\alpha-238$ G/A (high) & $1(6 \%)$ & $5(33 \%)$ \\
\hline $\begin{array}{l}\text { IL10 - 1082, }-819,-592 \\
\text { GCC/GCC (high) }\end{array}$ & & \\
\hline GCC/ACC (intermediate) & $9(53 \%)$ & $2(13 \%)^{* *}$ \\
\hline CTLA4 $-318 \mathrm{C} / \mathrm{C}$ & $12(71 \%)$ & $15(100 \%) \dagger$ \\
\hline $\begin{array}{l}\text { CTLA4 }(\mathrm{AT})_{\mathrm{n}} \text { repeats with } \mathrm{n}=25 \\
\text { or more }\end{array}$ & $7(41 \%) \ddagger$ & - \\
\hline \multicolumn{3}{|c|}{ 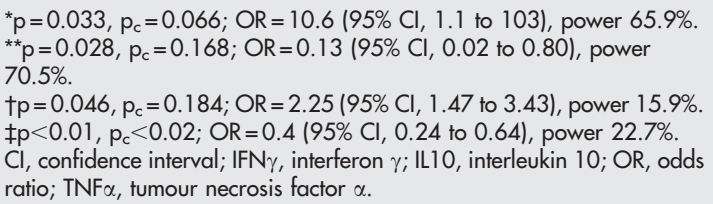 } \\
\hline
\end{tabular}

Table 2 Frequency of HLA-DRB 1 and HLA-DQB1 alleles in patients with Wegener's granulomatosis and healthy controls

\begin{tabular}{|c|c|c|}
\hline & Patients ( $n=32$ ) & Controls $(n=91)$ \\
\hline \multicolumn{3}{|l|}{ DRB 1} \\
\hline *01 & $6(19)$ & $24(26)$ \\
\hline$* 15$ & $8(25)$ & $28(31)$ \\
\hline$* 16$ & / & $3(3)$ \\
\hline${ }^{*} 03$ & $9(28) \dagger$ & 11 (12) \\
\hline${ }^{*} 04$ & $9(28)$ & $21(23)$ \\
\hline${ }^{*} 11$ & $5(16)$ & $19(21)$ \\
\hline *12 & $4(13)$ & $4(4)$ \\
\hline${ }^{*} 13$ & $5(16)$ & $24(26)$ \\
\hline$* 14$ & $3(9)$ & $8(9)$ \\
\hline${ }^{*} 07$ & 7 (22) & $20(22)$ \\
\hline *08 & $3(9)$ & $7(8)$ \\
\hline *09 & / & 1 (1) \\
\hline$* 10$ & $1(3)$ & 2 (2) \\
\hline \multicolumn{3}{|l|}{ DQB 1} \\
\hline${ }^{*} 02$ & $10(31)$ & 29 (32) \\
\hline${ }^{*} 0301$ & $5(16) t$ & 30 (33) \\
\hline *0302 & $6(19)$ & $18(20)$ \\
\hline${ }^{*} 0303$ & 4 (13) & $4(4)$ \\
\hline *04 & $3(9)$ & $5(6)$ \\
\hline${ }^{*} 0501$ & 7 (22) & $25(28)$ \\
\hline *0502 & / & $4(4)$ \\
\hline${ }^{*} 0503$ & $2(6)$ & 6 (7) \\
\hline${ }^{*} 0601$ & / & 2 (2) \\
\hline${ }^{*} 0602$ & $8(25)$ & 29 (32) \\
\hline${ }^{*} 0603$ & 3 (9) & $12(13)$ \\
\hline${ }^{*} 0604$ & 1 (3) & $9(10)$ \\
\hline *0609 & / & $2(2)$ \\
\hline
\end{tabular}

Values are $n(\%)$

tp value not significant.

cycles using $62^{\circ} \mathrm{C}$ as the annealing temperature. Polymorphisms in the promotor and first exon of the CTLA4 gene $(-318 \mathrm{C} / \mathrm{T},+49 \mathrm{~A} / \mathrm{G})$ were determined by PCR-SBT following amplification with 5'-AAGTCTCCACTTAGTTATC CAGA-3' as forward and 5'-GGGATGAAGAGAAGAAAA AAC $-3^{\prime}$ as reverse primer after 30 cycles, using $55^{\circ} \mathrm{C}$ as the annealing temperature. The PCR products were directly sequenced for both strands using the ABI BigDye ${ }^{\circledR}$ Terminator vl.l cycle sequencing kit (Applied Biosystems, Foster City, California, USA) and the initial amplification primers.

To analyse the $(\mathrm{AT})_{\mathrm{n}}$ repeats in the $3^{\prime}$ untranslated region of the CTLA4 gene, amplification using a fluorescence labelled antisense primer was carried out with the forward 5'-GCCAGTGATGCTAAAGGTTG-3' and reverse (FAM) 5'GTTTCTTAACATACGTGGCTCTATGCA-3' primer, for 30 cycles with $55^{\circ} \mathrm{C}$ as annealing temperature. The PCR products were analysed on an ABI 310 using the GeneScan ${ }^{\circledR}$ software and $400 \mathrm{HD}$ (ROX) size standard (Applied Biosystems). To define the number of AT repeats, homozygous samples were directly sequenced as described above using 5'-GTTTA TAGCCGAAATGATCT-3' as forward and 5'-AAAGACACTG CCATATAGTG-3' as reverse primers. The $(\mathrm{AT})_{\mathrm{n}}$ length polymorphism could thus be translated into the number of AT repeats, allowing better comparison between different studies.

\section{Statistical analysis}

Phenotype and genotype frequencies were compared between the patient and control group by the Yates corrected $\chi^{2}$ test for $2 \times 2$ tables or the Fisher's exact test as appropriate. Odds ratios (OR) were calculated with $95 \%$ confidence intervals (CI). Fisher's exact test was used for the subgroup analysis of the patient cohort. A probability $(\mathrm{p})$ value of $<0.05$ was considered significant. SPPS version 10.0 (SPSS Inc, Chicago, Illinois, USA) was used for all calculations. In addition, significant $\mathrm{p}$ values were subjected to Bonferroni correction 
(pc) by multiplying them by the number of antigens/alleles of a given locus compared for each HLA specificity or allele or single nucleotide polymorphism for which significance was found before correction. Reporting both the $\mathrm{p}$ values balances the need for minimising the risk of reporting spurious associations and the chance of overlooking a true association. Study size calculations were carried out for unmatched casecontrol studies with equal size for a power of $90 \%$ and a level of significance of $p=0.05$ (two sided), using the relative risk and the exposure rate among controls obtained in this study, according to Schlesselman ${ }^{21}$ :

$$
n=2 \bar{p} \bar{q}\left(z_{a}+z_{\beta}\right)^{2} /\left(p_{1}-p_{0}\right)^{2}
$$

Similarly, power calculations were undertaken for significant results based on the study size, exposure rate among controls, and the relative risk seen in this study:

$$
\begin{aligned}
\text { Power } & =1-\beta=P\left(Z \leq z_{\beta}\right) \\
z_{\beta} & =\left[n\left(p_{1}-p_{0}\right)^{2} / 2 \bar{p} \bar{q}\right]^{1 / 2}-z_{\alpha}
\end{aligned}
$$

\section{RESULTS}

\section{HLA-DRB 1 and HLA-DQB 1 analysis}

The results of the HLA-DRBI and HLA-DQBl genotyping are summarised in table 2 . No significant differences in allele frequencies between WG patients and healthy controls were found. There was only a trend towards a higher frequency for $\mathrm{DRBI}^{*} 03$ (28\% WG $\left.v 12 \% \mathrm{HC}, \mathrm{NS}\right)$ and a slight reduction of DQB ${ }^{*} 0301$ in WG patients ( $16 \%$ WG $v 33 \%$ HC, NS).

\section{IFN $\gamma$, TNF $\alpha$, TGF $\beta$, IL6, and IL 10 genotypes in WG}

A higher frequency of the IFN $\gamma$ intron $1+874 \mathrm{~T} / \mathrm{T}$ genotype was found in WG patients than in controls $(34 \% v 14 \%, \mathrm{p}=0.027$, $\mathrm{p}_{\mathrm{c}}=0.054 ; \mathrm{OR}=3.14(95 \% \mathrm{CI}, 1.23$ to 8.01$)$, power $\left.=46 \%\right)$. Also, the TNF $\alpha-238 \mathrm{G} / \mathrm{A}$ promotor genotype was found more often in WG patients $\left(19 \% v 4 \%, \mathrm{p}=0.029, \mathrm{p}_{\mathrm{c}}=0.058\right.$; OR 5.01 (95\% CI, 1.31 to 19.14), power $40.5 \%)$. No associations were found for the other two promotor polymorphisms. No significant differences between the WG patients and controls were seen for the IL6 - $174 \mathrm{C} / \mathrm{G}$ polymorphism and the TGF $\beta$ (codon $10 \mathrm{~T} / \mathrm{C}$ and $25 \mathrm{C} / \mathrm{G}$ ) and IL10 (promoter $-592 \mathrm{C} / \mathrm{A},-819 \mathrm{C} / \mathrm{T},-1082 \mathrm{G} / \mathrm{A}$ ) haplotype or genotype frequencies (data not shown). The results are summarised in table 3.

\section{CTLA4 genotypes in WG}

No differences in the CTLA4 $-318 \mathrm{C} / \mathrm{T}$ promotor and the exonl $+49 \mathrm{~A} / \mathrm{G}$ frequencies were noted between the patient and control group. Upon analysis of the AT repeats in the $3^{\prime}$ untranslated region of the CTLA4 gene we found 20 alleles with between seven and 33 AT repeats, giving rise to 400 potential genotypes. The number of identified AT repeats was in accordance with a previous report..$^{22}$ The genotypes $7 / 7$ and 7/16 represented half or more than half of the 38 genotypes actually identified in both cohorts. No significant differences in the allele or genotype distribution were noted between the two cohorts (data not shown).

\section{Stratification analysis of WG patients}

The patient cohort was divided according to whether or not the patients had developed end stage renal disease requiring haemodialysis or kidney transplantation. Both subgroups were similar with regard to age at diagnosis and disease duration (table 1). The IFN $\gamma+874 \mathrm{~A} / \mathrm{A}$ genotype was more prevalent in the ESRD subgroup (table 1). In contrast, the IFN $\gamma+874 \mathrm{~T} / \mathrm{T}$ genotype distribution did not show any

\begin{tabular}{|c|c|c|c|}
\hline Genotype & Phenotype & Patients ( $n=32$ ) & Controls $(\mathbf{n}=91)$ \\
\hline \multicolumn{4}{|c|}{ IFN $\gamma$ intron $+874(\mathrm{~A} / \mathrm{T})$} \\
\hline$T / T$ & High & $11(34)^{*}$ & $13(14)$ \\
\hline T/A & Intermediate & $14(44)$ & $53(58)$ \\
\hline $\mathrm{A} / \mathrm{A}$ & Low & $7(22)$ & $25(28)$ \\
\hline \multicolumn{4}{|c|}{ TGF $\beta 1$ codon 10 (T/C)/25 (C/G) } \\
\hline T/T G/G & High & $6(19)$ & $21(23)$ \\
\hline T/C G/G & High & $13(41)$ & $44(48)$ \\
\hline $\mathrm{T} / \mathrm{C} \mathrm{G} / \mathrm{C}$ & Intermediate & $3(9)$ & $7(8)$ \\
\hline$C / C G / G$ & Intermediate & $6(19)$ & $14(15)$ \\
\hline T/T G/C & Intermediate & $1(3)$ & / \\
\hline $\mathrm{C} / \mathrm{C} \mathrm{G} / \mathrm{C}$ & Low & $2(6)$ & $4(4)$ \\
\hline $\mathrm{C} / \mathrm{C} \mathrm{C} / \mathrm{C}$ & Low & $1(3)$ & $1(1)$ \\
\hline $\mathrm{T} / \mathrm{T} \mathrm{C} / \mathrm{C}$ & Low & / & / \\
\hline $\mathrm{T} / \mathrm{C} \mathrm{C} / \mathrm{C}$ & Low & / & / \\
\hline \multicolumn{4}{|c|}{ IL6 promotor - 174 (C/G) } \\
\hline G/G & High & $14(44)$ & $27(30)$ \\
\hline $\mathrm{G} / \mathrm{C}$ & High & $14(44)$ & $52(57)$ \\
\hline $\mathrm{C} / \mathrm{C}$ & Low & $4(13)$ & $12(13)$ \\
\hline \multicolumn{4}{|c|}{ IL10 promotor -1082 (G/A), -819 (C/T), -592 (C/A) } \\
\hline GCC/GCC & High & $6(19)$ & $19(21)$ \\
\hline GCC/ACC & Intermediate & $11(34)$ & $27(30)$ \\
\hline GCC/ATA & Intermediate & $11(34)$ & $24(26)$ \\
\hline $\mathrm{ACC} / \mathrm{ACC}$ & Low & $1(3)$ & $10(11)$ \\
\hline ACC/ATA & Low & $3(9)$ & $9(10)$ \\
\hline ATA/ATA & Low & & $2(2)$ \\
\hline \multicolumn{4}{|c|}{ TNF $\alpha$ promotor -376 (G/A), -308 (G/A), -238 (G/A) } \\
\hline$-376 \mathrm{G} / \mathrm{G}$ & Intermediate & $30(94)$ & $89(98)$ \\
\hline$-376 \mathrm{G} / \mathrm{A}$ & Intermediate & $2(6)$ & $2(2)$ \\
\hline$-376 \mathrm{~A} / \mathrm{A}$ & Intermediate & / & / \\
\hline$-308 \mathrm{G} / \mathrm{G}$ & Low & $24(75)$ & 79 (87) \\
\hline$-308 \mathrm{G} / \mathrm{A}$ & High & $6(19)$ & $10(11)$ \\
\hline$-308 \mathrm{~A} / \mathrm{A}$ & High & $2(6)$ & $2(2)$ \\
\hline$-238 G / G$ & Low & $26(81)$ & $87(96)$ \\
\hline$-238 G / A$ & High & 6(19)t & $4(4)$ \\
\hline$-238 \mathrm{~A} / \mathrm{A}$ & High & / & / \\
\hline \multicolumn{4}{|c|}{$\begin{array}{l}{ }^{*} \mathrm{p}=0.027, \mathrm{p}_{\mathrm{c}}=0.054 ; \mathrm{OR}=3.14(95 \% \mathrm{Cl}, 1.23 \text { to } 8.01) \text {, power } 46 \% \text {. } \\
t \mathrm{t}=0.029, \mathrm{p}_{\mathrm{c}}=0.058 ; \mathrm{OR}=5.01(95 \% \mathrm{Cl}, 1.31 \text { to } 19.14) \text {, power } \\
40.5 \% \text {. } \\
\mathrm{Cl} \text {, confidence interval; IFN } \gamma \text {, interferon } \gamma ; \mathrm{IL} \text {, interleukin; OR, odds ratio; } \\
\text { TGF } \beta 1 \text {, transforming growth factor } \beta 1 ; \mathrm{TNF} \alpha \text {, tumour necrosis factor } \alpha \text {. }\end{array}$} \\
\hline
\end{tabular}

Table 3 Cytokine gene polymorphism frequency in patients with Wegener's granulomatosis and controls

heterogeneity. A trend towards a higher frequency in the ESRD subgroup was observed for the TNF $\alpha-238 \mathrm{G} / \mathrm{A}$, the IL10 GCC/GCC, and the CTLA4 $-318 \mathrm{C} / \mathrm{C}$ genotype. In contrast, the IL10 GCC/ACC genotype was found more often in the non-ESRD subgroup. CTLA4 $(\mathrm{AT})_{\mathrm{n}}$ alleles with 25 or more repeats were found in the non-ESRD subgroup only.

\section{Study size calculations}

Based on the uncorrected p values, significant associations were subjected to study size calculations aiming at a level of significance $\alpha=0.05$ (two sided) and power $\beta=0.1$ (that is, $90 \%$ and an equal size of patient and control groups). For the analysis of IFN $\gamma+874 \mathrm{~T} / \mathrm{T}$ a cohort of at least 97 patients was needed. Similarly, the study of TNF $\alpha-238 \mathrm{G} / \mathrm{A}$ polymorphism required at least 113 patients. For the comparison of ESRD positive and ESRD negative patients for IFN $\gamma+874$ $\mathrm{A} / \mathrm{A}$, at least 32 patients each would be required, and for the study of the CTLA $4-318 \mathrm{C} / \mathrm{C}$ polymorphism a minimum of 195 patients. The study size requirements were 29 and 122 for the IL10 GCC/ACC promotor polymorphism and for the long CTLA4 $(\mathrm{AT})_{\mathrm{n}}$ repeats, respectively.

\section{DISCUSSION}

In this exploratory study, we focused on a cohort of PR3ANCA positive WG patients with renal involvement, to explore the relevance of HLA markers, cytokine polymorphism, and genetic CTLA4 variants for disease susceptibility and 
the occurrence of end stage renal disease as a serious complication of WG.

As WG is a rare disease with an approximate prevalence of 23.7 per million adults, ${ }^{1}$ studies such as ours and others recently published ${ }^{15-1823}$ on the immunogenetics of WG are prone to deficient statistical power to clarify the associations of genetic markers with disease susceptibility and outcome. Thus the heterogeneity detected in this study requires further investigation in larger cohorts, possibly multicentre studies, as confirmed by the calculations of the sample sizes needed to provide definitive evidence of the modulatory effects of immunoregulatory genes. Nevertheless, our study may help in the selection of immunoregulatory genes for further study in this candidate gene approach, as discussed in more detail below.

In our study we did not observe any predispositional or preventive effects of the HLA-DRBI and DQBI alleles analysed. When IFN $\gamma$ intron 1 polymorphism was investigated, a complex association pattern was seen. While the IFN $\gamma$ high expressor $\mathrm{T} / \mathrm{T}$ genotype ${ }^{24}$ was associated with disease occurrence, it was not increased in the subgroup of WG patients who had developed ESRD. In contrast, the +874 A/A genotype-a low expressor phenotype ${ }^{25}$ - was increased in ESRD positive patients compared with the remainder. IFN $\gamma$ as part of a T-helper 1 cytokine pattern has been implicated previously in the pathogenesis of WG..$^{7-9}$ Thus distinct IFN $\gamma$ polymorphisms may modulate disease susceptibility and outcome.

Similarly, $\mathrm{TNF} \alpha$, another important proinflammatory cytokine produced in peripheral or granuloma $\mathrm{T}$ cells from WG patients, seems to play an important role in the pathogenesis. ${ }^{79}$ Our data indicate a role for the TNF $\alpha-238$ G/A genotype, which is associated with a high cytokine expressor phenotype ${ }^{26}$ for disease susceptibility and renal involvement. The observed lack of association of WG with the $\mathrm{TNF} \alpha$ promoter -308 polymorphism is in accordance with previous studies. ${ }^{18} 2327$

Interleukin 10 seems to play a dual role in both localised and generalised WG. ${ }^{4}{ }^{7}$ Moreover, distinct IL10 polymorphisms have previously been associated with WG. ${ }^{15}{ }^{16}$ In our cohort we did not find any differences in the frequencies of the IL10 promotor polymorphisms investigated. However, in the subgroup analysis, WG patients without ESRD showed a higher prevalence of the IL10 GCC/ACC promoter haplotype, which had been associated with an intermediate expressor phenotype..$^{25}$ Thus IL10 polymorphisms may be related to disease course in WG. The possibility that cytokine polymorphisms may influence disease outcome in WG is supported by a recent study by Borgmann and colleagues, who showed that the proinflammatory genotype of ILl and the ILl receptor antagonist were associated with ESRD rather than with disease susceptibility in patients with PR3-ANCA vasculitis. $^{29}$

Two previous studies had suggested associations of the CTLA4 $(\mathrm{AT})_{\mathrm{n}}$ repeat and promotor polymorphisms with WG. ${ }^{17}{ }^{23}$ However, in our study we did not find a reduction in the CTLA4 $-318 \mathrm{C} / \mathrm{C}$ genotype, though in the subgroup analysis the $-318 \mathrm{C} / \mathrm{C}$ genotype was increased in WG patients who did not develop ESRD. We could not detect a reduction in the frequency of the shortest $(\mathrm{AT})_{\mathrm{n}}$ allele and the resulting genotypes, in contrast to Huang et al. ${ }^{23}$ However, in the subgroup analysis alleles with 25 or more AT repeats were found exclusively in the WG subgroup which did not develop ESRD. These discrepancies between studies may reflect the low power of the individual studies, or differences in patient selection and disease heterogeneity.

Patients with systemic vasculitis including ANCA associated vasculitis have raised plasma levels of TGF $\beta$, which can also serve as a translocation factor for proteinase $3 .{ }^{11} 30$
Despite this potential role of TGF $\beta$ in the pathogenesis of WG, we did not observe any distinction between the WG and control group with respect to the TGF $\beta$ codon 10 and 25 polymorphisms.

\section{Conclusions}

The data suggest that distinct IFN $\gamma$ polymorphisms are associated with disease susceptibility and outcome in generalised WG. In addition, the TNF $\alpha-238 \mathrm{G} / \mathrm{A}$ genotype may contribute to disease susceptibility. $\mathrm{T}$ cell regulatory gene polymorphisms (IL10, CTLA4) appear to be associated with disease outcome alone rather than with susceptibility to generalised WG.

\section{Authors' affiliations}

B M Spriewald, M-L Arnold, J R Kalden, Institute for Clinical Immunology, Department of Medicine III, University Erlangen-Nürnberg, Erlangen, Germany

O Witzke, R R Wenzel, T Philipp, Department of Nephrology, University Hospital Essen, Essen, Germany

R Wassmuth, Institute for Transplantation Diagnostics and Cell

Therapeutics, University Medical Centre, Düsseldorf, Germany

\section{REFERENCES}

1 Mahr A, Guillevin L, Poissonnet M, Ayme S. Prevalences of polyarteritis nodosa, microscopic polyangiitis, Wegener's granulomatosis, and ChurgStrauss syndrome in a French urban multiethnic population in 2000: a capture-recapture estimate. Arthritis Rheum 2004;51:92-9.

2 Kallenberg CG, Rarok A, Stegeman CA. Genetics of ANCA-associated vasculitides. Cleve Clin J Med 2002;69:SIl61-3.

3 Griffith ME, Pusey CD. HLA genes in ANCA-associated vasculitides. Exp Clin Immunogenet 1997; 14:196-205.

4 Muller A, Trabandt A, Gloeckner-Hofmann K, Seitzer U, Csernok E, Schonermarck $U$, et al. Localized Wegener's granulomatosis: predominance of CD26 and IFN-gamma expression. J Pathol 2000;192:113-20.

5 Schlesier M, Kaspar T, Gutfleisch J, Wolff-Vorbeck G, Peter HH. Activated CD4+ and CD8+ T-cell subsets in Wegener's granulomatosis. Rheumatol Int 1995; 14:213-19.

6 Moosig F, Csernok E, Wang G, Gross WL. Costimulatory molecules in Wegener's granulomatosis (WG): lack of expression of CD28 and preferential up-regulation of its ligands B7-1 (CD80) and B7-2 (CD86) on T cells. Clin Exp Immunol 1998;114:113-18.

7 Ludviksson BR, Sneller MC, Chua KS, Talar-Williams C, Langford CA, Ehrhardt RO, et al. Active Wegener's granulomatosis is associated with HLADR+ CD4+ T cells exhibiting an unbalanced Th1-type T cell cytokine pattern: reversal with IL-10. J Immunol 1998;160:3602-9.

8 Csernok E, Trabandt A, Muller A, Wang GC, Moosig F, Paulsen J, et al. Cytokine profiles in Wegener's granulomatosis: predominance of type 1 (Th1) in the granulomatous inflammation. Arthritis Rheum 1999;42:742-50.

9 Komocsi A, Lamprecht P, Csernok E, Mueller A, Holl-Ulrich K, Seitzer U, et al. Peripheral blood and granuloma CD4(+)CD28(-) T cells are a major source of interferon-gamma and tumor necrosis factor-alpha in Wegener's granulomatosis. Am J Pathol 2002;160:1717-24.

10 Csernok E, Ernst M, Schmitt W, Bainton DF, Gross WL. Activated neutrophils express proteinase 3 on their plasma membrane in vitro and in vivo. Clin Exp Immunol 1994;95:244-50.

11 Csernok E, Szymkowiak CH, Mistry N, Daha MR, Gross WL, Kekow J. Transforming growth factor-beta (TGF-beta) expression and interaction with proteinase 3 (PR3) in anti-neutrophil cytoplasmic antibody (ANCA)-associated vasculitis. Clin Exp Immunol 1996;105:104-11.

12 Mayet WJ, Hermann EM, Csernok E, Gross WL, Meyer zum Buschenfelde KH. In vitro interactions of c-ANCA (antibodies to proteinase 3) with human endothelial cells. Adv Exp Med Biol 1993;336:109-13.

13 Reumaux D, Duthilleul P, Roos D. Pathogenesis of diseases associated with antineutrophil cytoplasm autoantibodies. Hum Immunol 2004;65:1-12.

14 Harper L, Savage CO. Pathogenesis of ANCA-associated systemic vasculitis. J Pathol 2000;190:349-59.

15 Zhou Y, Giscombe R, Huang D, Lefvert AK. Novel genetic association of Wegener's granulomatosis with the interleukin 10 gene. J Rheumatol 2002;29:317-20.

16 Murakozy G, Gaede KI, Ruprecht B, Gutzeit O, Schurmann M, Schnabel A, et al. Gene polymorphisms of immunoregulatory cytokines and angiotensinconverting enzyme in Wegener's granulomatosis. J Mol Med 2001;79:665-70.

17 Giscombe R, Wang X, Huang D, Lefvert AK. Coding sequence 1 and promoter single nucleotide polymorphisms in the CTLA-4 gene in Wegener's granulomatosis. J Rheumatol 2002;29:950-3.

18 Mascher B, Schmitt W, Csernok E, Tatsis E, Reil A, Gross WL, et al. Polymorphisms in the tumor necrosis factor genes in Wegener's granulomatosis. Exp Clin Immunogenet 1997;14:226-33.

19 Leavitt RY, Fauci AS, Bloch DA, Michel BA, Hunder GG, Arend WP, et al. The American College of Rheumatology 1990 criteria for the classification of Wegener's granulomatosis. Arthritis Rheum 1990;33:1101-7. 
20 Jennette JC, Falk RJ, Andrassy K, Bacon PA, Churg J, Gross WL, et al. Nomenclature of systemic vasculitides. Proposal of an international consensus conference. Arthritis Rheum 1994;37:187-92.

21 Schlesselman JJ. Case-control studies. Design, conduct, analysis. Oxford: Oxford University Press, 1982.

22 Rodriguez MR, Nunez-Roldan A, Aguilar F, Valenzuela A, Garcia A, Gonzalez-Escribano MF. Association of the CTLA4 3' untranslated region polymorphism with the susceptibility to rheumatoid arthritis. Hum Immunol 2002:63:76-81.

23 Huang D, Giscombe R, Zhou Y, Lefvert AK. Polymorphisms in CTLA-4 but not tumor necrosis factor-alpha or interleukin 1 beta genes are associated with Wegener's granulomatosis. J Rheumatol 2000;27:397-401.

24 Pravica V, Perrey C, Stevens A, Lee JH, Hutchinson IV. A single nucleotide polymorphism in the first intron of the human IFN-gamma gene: absolute correlation with a polymorphic CA microsatellite marker of high IFN-gamma production. Hum Immunol 2000;61:863-6.

25 Hoffmann SC, Stanley EM, Darrin Cox E, Craighead N, DiMercurio BS, Koziol DE, et al. Association of cytokine polymorphic inheritance and in vitro cytokine production in anti-CD3/CD28-stimulated peripheral blood lymphocytes. Transplantation $2001 ; 72: 1444-50$.
26 Reich K, Mossner R, Konig IR, Westphal G, Ziegler A, Neumann C. Promoter polymorphisms of the genes encoding tumor necrosis factor-alpha and interleukin-1 beta are associated with different subtypes of psoriasis characterized by early and late disease onset. J Invest Dermatol 2002; 118:155-63.

27 Gencik M, Borgmann S, Zahn R, Albert E, Sitter T, Epplen JT, et al. Immunogenetic risk factors for anti-neutrophil cytoplasmic antibody (ANCA)-associated systemic vasculitis. Clin Exp Immunol

1999;117:412-17.

28 Suarez A, Castro P, Alonso R, Mozo L, Gutierrez C. Interindividual variations in constitutive interleukin-10 messenger RNA and protein levels and their association with genetic polymorphisms. Transplantation 2003;75:711-17

29 Borgmann S, Endisch G, Hacker UT, Song BS, Fricke H. Proinflammatory genotype of interleukin-1 and interleukin-1 receptor antagonist is associated with ESRD in proteinase 3-ANCA vasculitis patients. Am J Kidney Dis 2003;41:933-42.

30 Kekow J, Csernok E, Szymkowiak C, Gross WL. Interaction of transforming growth factor beta (TGF beta) with proteinase 3. Adv Exp Med Biol 1997; 421:307-13. 